\title{
Assessment of the Effect of Application of the Herbicide S-Metolachlor on the Activity of Some Enzymes Found in Soil
}

\author{
Marioara Nicoleta Filimon ${ }^{1,2, *}$, Diana Larisa Roman ${ }^{1,2}$, Ion Valeriu Caraba ${ }^{3, *}$ and Adriana Isvoran ${ }^{1,2}$ (D) \\ 1 Department Biology-Chemistry, Faculty of Chemistry-Biology-Geography, West University of Timisoara, \\ Pestalozzi 16, 300315 Timisoara, Romania; diana.roman@e-uvt.ro (D.L.R.); adriana.isvoran@e-uvt.ro (A.I.) \\ 2 Advanced Environmental Research Laboratories (AERL), Oituz 4, 300086 Timisoara, Romania \\ 3 Faculty of Bioengineering of Animal Resources, Banat University of Agricultural Sciences and Veterinary \\ Medicine "King Mihai I of Romania" from Timisoara, Calea Aradului 119, 300645 Timisoara, Romania \\ * Correspondence: marioara.filimon@e-uvt.ro (M.N.F.); caraba_i@animalsci-tm.ro (I.V.C.)
}

check for updates

Citation: Filimon, M.N.; Roman, D.L.; Caraba, I.V.; Isvoran, A. Assessment of the Effect of Application of the Herbicide S-Metolachlor on the Activity of Some Enzymes Found in Soil. Agriculture 2021, 11, 469. https:// doi.org/10.3390/agriculture11060469

Academic Editor: Maria Dolores Osuna Ruiz

Received: 3 April 2021

Accepted: 18 May 2021

Published: 21 May 2021

Publisher's Note: MDPI stays neutral with regard to jurisdictional claims in published maps and institutional affiliations.

Copyright: (C) 2021 by the authors Licensee MDPI, Basel, Switzerland. This article is an open access article distributed under the terms and conditions of the Creative Commons Attribution (CC BY) license (https:// creativecommons.org/licenses/by/ $4.0 /)$.

\begin{abstract}
Herbicides are being used more and more to increase productivity in agriculture, but their excessive has been shown to lead to adverse effects on the environment, especially on the soil. Within this study the effect of the herbicide S-metolachlor on the activity of several enzymes (dehydrogenase, protease, phosphatase and urease) found in the loamy-clayey soil has been analyzed. There were seven experimental variants corresponding to the untreated soil and to the application of six distinct doses of S-metolachlor on soil samples maintained in laboratory conditions. Biochemical analyzes have been performed to assess the activities of the investigated enzymes at 7, 14 and 21 days, respectively, and several physiochemical parameters of the soil have been also monitored during these experiments. The data obtained in the experimental determinations were subjected to statistical analysis such as to evaluate if the changes in the activities of enzymes are significant and to establish if there are correlations between the evolution of analyzed enzymatic activities and the physicochemical parameters of the soil. Molecular docking approach has been also used to assess the interactions between the herbicide and investigated enzymes. The activities of studied enzymes decreased in a dose-dependent manner when the herbicide was applied. More than 21 days were necessary to recover the activities of dehydrogenase and protease in the soil treated with S-metolachlor, the activity of protease was recovered after 14 days and the activity of urease was recuperated after 7 days of incubation. This study also emphasized significant correlations between the enzymatic activities and some physicochemical parameters of the soil: $\mathrm{pH}$, moisture, organic matter, nitrogen level and available phosphorus.
\end{abstract}

Keywords: S-metolachlor; enzymatic activity; soil physicochemical properties; molecular docking; statistical analysis

\section{Introduction}

In recent years, there have been many changes in agriculture that have led to a substantial increase in the global use of pesticides. Herbicides are considered the most economical and effective method of controlling weeds in both agricultural and uncultivated lands. However, the increase in the use of herbicides has led to water and soil pollution, to ecological problems and, last but not least, to a negative impact on the environment with repercussions on the health of animals and humans.

Herbicides are applied to increase agricultural productivity and crop yields, but their inappropriate and excessive use can have adverse effects on the environment, especially on the soil [1,2]. Soil is a major component of terrestrial ecosystems and a source of nutrients for plants and various organisms. Soil has the role of supporting biological processes, acts as a buffer to protect groundwater and plants against pollution, and it also prevents the transfer of pollutants [3]. Maintaining and improving soil quality is based on biochemical processes and the activity of communities of microorganisms that are present in the soil. 
The communities of the soil microorganisms and the activities of the enzymes found in the soil are considered as basic indicators of the fertility and pollution status of the soil. There is a prompt response of these characteristics to environmental alterations, reflecting the biological changes caused by pollution and contamination [4-6]. Pesticides applied to crops can cause changes in soil metabolism [7], may influence the communities of soil microorganisms causing their qualitative and quantitative changes (i.e., structure, abundance and diversity) $[5,8,9]$, but they also affect the activity of enzymes found in the soil $[4,10-12]$. The activities of enzymes found in the soil can provide information on the transformation of pesticides, the enzymes from the group of hydrolases (dehydrogenase, urease) being the most frequently used in this purpose and are also considered as potential indicators of the soil quality $[13,14]$. Phosphatases are other enzymes that are used for assessing the soil quality and fertility as they play an important role in the phosphorus circuit in the soil, are capable of catalyzing the hydrolysis of esters and anhydrides of phosphoric acid in the soil, and are positively correlated to phosphorus stress and plant growth [15].

The applied pesticides can be also degraded in the soil and, consequently their toxic effect on the environment may be reduced. Specific literature data reveal that the metabolic activity of the soil treated with herbicides is influenced by biotic parameters (the relationships established between the groups of soil microorganisms), but especially by the abiotic parameters: soil type and texture, physicochemical parameters of the soil (temperature, $\mathrm{pH}$, humidity, inorganic and organic matter content), and by the herbicide type and applied dose $[9,16-18]$.

The herbicide S-metolachlor, (IUPAC name 2-chloro- $N$-(2-ethyl-6-methylphenyl)- $N$ [(2S)-1-methoxypropan-2-yl]acetamide), is one of the three most used herbicides in the world in the chloroacetanilide class. This herbicide has a high toxicity and it can be leached, representing a powerful source of groundwater pollution [19]. Generally, acetanilide residues and their metabolites are common in aquifers in close proximity to agricultural soils where these herbicides have been applied. Acetanilide biodegradation is a very important factor for its elimination in aerobic and anaerobic environments. Due to its moderate to long persistence in soil, high ability to infiltrate groundwater and its low ability to adhere to soil particles, S-metolachlor and its metabolites are commonly found in ground and surface water $[20,21]$. This observation, added to data on the bioaccumulation of S-metolachlor, conducted to an increased concern about its safety for both environmental and human health. Attempts have been made to propose strategies on the application of S-metolachlor, given its effectiveness on weed control in crops, but at the same time to minimize its harmful effects on the quality of the environment. Studies have been conducted to investigate the effects of several environmental factors, including soil properties (temperature, humidity), presence of microorganisms and applied dose of the herbicide on the rate of S-metolachlor degradation [22]. A study by Wołejko and co-authors in 2017 [22] confirmed that S-metolachlor application may have contributed to the increase in dehydrogenase activity in the soil between the 2nd and 28th days after the application and a decrease in dehydrogenase activity in the soil after the 28th day. Other studies that have been conducted regarded the S-metolachlor adsorption, degradation, leaching and mobility capacity in soil $[20,23]$. These studies revealed that the dissipation of S-metolachlor was faster on alkaline soils compared with acidic soils and that after the application of herbicide the enzymatic activity was increased in the soil samples with a higher $\mathrm{pH}$. Ulea and its co-workers revealed in their study that microbial populations reacted to the application of S-metolachlor by increasing biomass and enzymatic activity [24].

We have identified two earlier studies dealing respectively with the effect of the herbicide S-metolachlor [22] and of a mixture of herbicides containing this herbicide [25] on the activity of enzymes found in the soil. These studies were conducted on sandy soil characteristic of northeastern Poland. Even if the physicochemical properties of soils are usually considered the most important factors influencing the soil organic carbon and nutrients availability with direct consequences on the activity of enzymes found in soil, 
the soil complexity cannot be fully reproduced by the physicochemical parameters that are usually considered in experiments dedicated to characterize the soil [26]. Taking into consideration that soil physical properties (sand, loam or clay), climate, productivity, and soil biodiversity are also important factors affecting the biochemical processes taking place in the soil [26], the novelty of our study consists in assessing the effects of the herbicide Smetolachlor on the activity of enzymes found in a loamy-clayey soil that is characteristic for the western region of Romania. To the best of our knowledge, this is the first study dealing with an investigation of the effects of the herbicide S-metolachlor on the activity of enzymes considering this type of soil. The objectives of the present study are: (i) investigation of the influence of the herbicide S-metolachlor on the activities of some enzymes found in soil; (ii) evaluation of the influence of the physicochemical properties of the soil treated with the herbicide on the activities of enzyme.

\section{Materials and Methods}

\subsection{Herbicide}

S-Metolachlor (Figure 1) is a very important chloroacetanilide herbicide classified as an inhibitor of very-long-chain fatty acid formation and widely used for pre-emergence and post-emergence weed control in a variety of crops (corn, soybean, peanuts, sorghum, cotton). It is also used in combination with other herbicides.<smiles>CCc1cccc(C)c1N(C(=O)CCl)C(C)COC</smiles>

Figure 1. Structural formula of S-metolachlor [27].

The experiments were performed using a product sold on a local market under the trade name "Dual Gold 960 CE" (Syngeta, Basel, Switzerland) (herbicide selective, preand post-emergent), that contains $960 \mathrm{~g} / \mathrm{L}$ S-metolachlor. Pre-emergent herbicides ensure superior and long lasting control, especially of grass-type weeds but also some weeds with broad leaves [28].

\subsection{Soil Sampling}

The soil samples were collected from an experimental field located nearby Timisoara city $\left(45^{\circ} 45^{\prime} 14.54^{\prime \prime} \mathrm{N}, 21^{\circ} 18^{\prime} 16.66^{\prime \prime} \mathrm{E}\right)$, in an area where insecticides, fungicides, herbicides or chemical fertilizers were never used. The soil used in the experiment comes from a non-agricultural area. Chernozem soil samples were collected from the top layer of soil $(0-20 \mathrm{~cm})$ from five different spots in quantities varying between 20 and $25 \mathrm{~kg}$. The material was ground, sieved $(2 \mathrm{~mm})$ and spooned by random sampling, giving sub-samples of $10 \mathrm{~kg}$ soil. The samples were preserved in a refrigerator and processed as soon as possible during the following 30 days.

Biochemical and microbiological analyses were performed on soil samples grouped in 7 experimental variants corresponding to the 6 applied doses of S-metolachlor (Table 1). Soil samples were incubated under laboratory conditions with controlled values of physicochemical parameters (temperature and humidity kept constant). 
Table 1. Experimental variants considered in this study.

\begin{tabular}{cc}
\hline Experimental Variants & Dose Application in Soil \\
\hline M & control soil (soil untreated with S-metolachlor) \\
V1 & $1 \mathrm{~g}$ S-metolachlor $/ \mathrm{kg}$ of soil \\
V2 & $3 \mathrm{~g}$ S-metolachlor $/ \mathrm{kg}$ of soil \\
V3 & $6 \mathrm{~g}$ S-metolachlor $/ \mathrm{kg}$ of soil \\
V4 & $9 \mathrm{~g}$ S-metolachlor $/ \mathrm{kg}$ of soil \\
V5 & $12 \mathrm{~g} \mathrm{S-metolachlor} / \mathrm{kg}$ of soil \\
\hline
\end{tabular}

\subsection{Treatment of Soil Samples with Herbicides}

The experimental variants that were considered are presented in Table 1. The application of the herbicide was performed by spraying on the soil surface for every experimental variant. S-Metolachlor solutions in the concentrations established for each experimental variant were applied uniformly on the soil surface. The quantity of solution applied was determined according to the quantity of soil in each experimental variant to ensure the established concentration. The soil was incubated for 21 days under laboratory conditions.

\subsection{Physicochemical Properties of Soil}

Monitored physicochemical parameters of every experimental variant were the temperature $(\mathrm{T}), \mathrm{pH}$, electrical conductivity (EC), soil organic matter, water, $\mathrm{NH}_{4}-\mathrm{N}, \mathrm{NO}_{3}-\mathrm{N}$ and phosphate content in soil. Some physicochemical parameters of the soil (temperature, $\mathrm{pH}, \mathrm{EC}$ ) were measured by using a handheld Multi 340i/SET multimeter (WTW, Weilheim, Germany) fitted with specific sensors for each parameter. Soil samples were extracted with distilled water, 1:1 water to soil suspension and the soil $\mathrm{pH}$ value has been measured. Measurement of the soil electrical conductivity has been done using a suspension 5:1 distilled water to soil.

In order to determine the water content in the soil, thermogravimetric analysis of the samples was carried out using a thermobalance MA50 (Sartorius AG, Göttingen, Germany) which permits monitoring the dehydration of the evaluated products by a constant weighing during the dehydration process. $5 \mathrm{~g}$ of each investigated sample was oven dried at $105^{\circ} \mathrm{C}$ to constant weight using thermo-gravimetric method [29].

Determination of total organic matter content (humus) in the soil has been achieved by calcination method. It is based on the principle of elimination by calcination of an organic substance in the sample as a result of the oxidation of carbon with atmospheric oxygen. The weight loss by combustion is determined by weighing. The soil samples were calcined in a muffle furnace, where the temperature was gradually increased up to $550{ }^{\circ} \mathrm{C}$ and held constant for $4 \mathrm{~h}$. The amount of organic matter $(\mathrm{H} \%)$ for each soil sample was calculated as follows:

$$
H \%=\frac{m_{1}-m_{2}}{m_{1}} \times 100
$$

where $m_{1}$ is the weight of the soil sample at room temperature and $m_{2}$ is the weight of the ash sample [30].

The determination of ammonium $\left(\mathrm{NH}_{4}-\mathrm{N}\right)$ content in each of the soil samples was performed by using a spectrophotometer T90 UV/Vis (PG Instruments, Lutterworth, UK) at a wavelength of $630 \mathrm{~nm}$ as described by Baethgen and Alley [31].

The determination of nitrate $\left(\mathrm{NO}_{3}-\mathrm{N}\right)$ content in each of the soil samples was performed by using T90 UV/Vis spectrophotometer (PG Instruments) at a wavelength of $543 \mathrm{~nm}$ as described by Uwah and co-authors [32]. The concentration levels of nitrate $\left(\mu \mathrm{g} \mathrm{g}^{-1}\right)$ in the samples were calculated using the following equation:

$$
\mathrm{NO}_{3}^{-}\left(\mu g g^{-1}\right)=c_{\mathrm{NO}_{3}^{-}} \frac{\mathrm{V}}{\mathrm{m}}
$$


where $c_{\mathrm{NO}_{3}^{-}}$is the concentration of $\mathrm{NO}_{3}^{-}$in the sample (ppm), $V$ is the total volume of the sample solution and $m$ is the weight of the sample.

The determination of content of phosphate in each of the soil samples was performed by using T90 UV/Vis spectrophotometer (PG Instruments). Phosphate content was determined using a spectrophotometer at a wavelength of $882 \mathrm{~nm}$ [33].

\subsection{Biochemical Analyses}

The enzymes chosen for activity assays were: dehydrogenase (EC 1.1.1.1), urease (EC 3.5.1.5), phosphatase (EC 3.1.3.2) and protease (EC 3.4.21.19). Dehydrogenase activity (DA) was measured using 2,3,5-triphenyltetrazolium chloride (TTC) as substrate, monitoring the reaction product (triphenylformazane, TPF) at $485 \mathrm{~nm}$. The reaction mixture containing $3 \mathrm{~g}$ soil sample, $0.5 \mathrm{~mL}$ of $3 \%$ solution of TTC, $1.2 \mathrm{~mL}$ Tris buffer $(0.1 \mathrm{M}, \mathrm{pH} 7.6)$ was kept at $37^{\circ} \mathrm{C}$ for $48 \mathrm{~h}$. TPF was extracted with $20 \mathrm{~mL}$ acetone and the absorbance of the supernatant was measured at $485 \mathrm{~nm}$. The DA is expressed as $\mathrm{mg} \mathrm{TPF}^{-1}$ soil during $48 \mathrm{~h}$ [34].

Urease activity (UA) assesses the rate of urea decomposition in ammonia $\left(\mathrm{NH}_{3}\right)$ and carbon dioxide $\left(\mathrm{CO}_{2}\right)$. For each sample, five grams of soil were placed in a sterile polyethylene tube containing $2 \mathrm{~mL}$ toluene, $5 \mathrm{~mL}$ phosphate buffer, and $5 \mathrm{~mL}$ of $5 \%$ urea solution $\left(\mathrm{CH}_{4} \mathrm{~N}_{2} \mathrm{O}\right)$. The mixture was incubated at $37^{\circ} \mathrm{C}$, for $24 \mathrm{~h}$. The absorbance was measured at $445 \mathrm{~nm}$ and the UA is expressed as $\mathrm{mg} \mathrm{NH}_{3}-\mathrm{N} \mathrm{g}^{-1} \mathrm{~h}^{-1}$ soil during $24 \mathrm{~h}$ [35].

Phosphatase activity (PhA) was estimated based on hydrolytic separation of phenyl phosphate by phosphomonoesterases, the final products being disodium phosphate and phenol. The latter compound reacts with Gibbs reagent (2,6-dibromchinone chloramide) and a blue precipitate results. For each sample, about $2.5 \mathrm{~g}$ sediment was placed in a test tube containing $10 \mathrm{~mL}$ of $0.5 \%$ disodium phosphate solution. The mixture was incubated at $37^{\circ} \mathrm{C}$ for $48 \mathrm{~h}$. Next, $50 \mathrm{~mL}$ of ammonium aluminum sulphate $\left(\mathrm{NH}_{4} \mathrm{Al}\left(\mathrm{SO}_{4}\right)_{2} \times 12 \mathrm{H}_{2} \mathrm{O}\right)$, were added to each test tube and the mixtures were then filtered through ash-free filter paper. From each test tube, $1 \mathrm{~mL}$ filtrate was transferred to an empty test tube, together with $5 \mathrm{~mL}$ of borax solution $\left(\mathrm{Na}_{2} \mathrm{~B}_{4} \mathrm{O}_{7} \times 10 \mathrm{H}_{2} \mathrm{O}, \mathrm{pH}=9.4\right)$. The mixture was brought to a volume of $25 \mathrm{~mL}$ with bidistilled water. PhA was determined at $597 \mathrm{~nm}$. The calibration curve was constructed by using a $50 \mu \mathrm{g} / \mathrm{mL}$ phenol $\left(\mathrm{C}_{6} \mathrm{H}_{5} \mathrm{OH}\right)$ solution. PhA was defined as $\mu \mathrm{g}$ phenol $\mathrm{g}^{-1}$ soil during $48 \mathrm{~h} \mathrm{[36] \text {. }}$

The protease activity (PA) was estimated by reaction of ninhydrin with the amino acids resulting from the hydrolysis of gelatin used as substrate. For each sample, about $3 \mathrm{~g}$ of soil was mixed with $7 \mathrm{~mL}$ of $2 \%$ gelatin and $0.5 \mathrm{~mL}$ toluene. The mixture was homogenized ( $2 \mathrm{~min}$ on vortex) and incubated at $37^{\circ} \mathrm{C}$ for $24 \mathrm{~h}$. Next, $25 \mathrm{~mL}$ of distilled water was added and the mixture was filtered through ash-free filter paper. From each test tube, $2 \mathrm{~mL}$ of filtrate was transferred to an empty test tube together with $5 \mathrm{~mL}$ of $0.2 \%$ ninhydrin solution and the absorbance was measured at $578 \mathrm{~nm}$. The PA was defined as mg amino- $\mathrm{N} \mathrm{g}^{-1} \mathrm{~h}^{-1}$ soil during $24 \mathrm{~h}[9,37]$.

Determinations of enzymatic activities were performed after 7, 14 and respectively 21 days of incubation of the soil with S-metolachlor. All measurements of enzymatic activities were performed by using a T90 UV/Vis spectrophotometer (PG Instruments). For each soil sampling, the analytic protocol was carried out in triplicate, in a controlled laboratory environment, by the same researcher on the same day. The sampling protocol relied on collecting independent soil samples, that is at each time point and for each treatment group the soil samples were collected randomly, and not from the same locations.

\subsection{Statistical Analysis}

Prior to the ANOVA test, the log-transformed data (decimal logarithm) for investigated enzymatic activities, that is dehydrogenase activity (DA), urease activity (UA), protease activity (PA), and phosphatase activity (PhA), were verified for normality using Anderson-Darling tests and for homogeneity of variances for each combination of the groups of the two independent variables with Bartlett's tests. Enzymatic activities for 
which both conditions were met, have been further analyzed in a two-way ANOVA, with the herbicide dose and exposure time as variables.

Post hoc analysis was performed using the Tukey's HSD approach for each significant main effect, with all pairwise comparisons for herbicide dose and exposure time being made against controls and the earliest time point, respectively. In the case of a significant interaction effect between the two predictors, these comparisons were performed at each time point using the corresponding controls as benchmark groups.

For heteroscedastic variables, Kruskal-Wallis tests were first applied on pooled data sets for herbicide dose and exposure time, with Dunn's post hoc tests being used in case of significant differences. If both these tests yielded significant results, Kruskal-Wallis tests with post hoc Dunn's tests were next conducted at each time point to study the effect of the interaction between these two predictors. For each analyzed enzymatic activity, Tukey's HSD tests (for homoskedastic data) or Dunn's tests (for heteroskedastic data) were also used to compare the measured values for the treated samples with those obtained for control samples and the measured values at 14 days and 21 days with those measured at 7 days. Finally, Spearman's correlations were applied on pooled average values for enzymatic activities and the measured values for selected physicochemical soil parameters $(\mathrm{pH}$, temperature, moisture, organic matter content, nitrogen level, ammonia level and available phosphorus). All statistical analyses were performed with Statistica version 7 (StatSoft Inc., Tulsa, OK, USA). In all cases, a $p$ value $<0.05$ was considered significant.

\subsection{Computational Approach}

We have used the molecular docking approach to assess the interactions of S-metolachlor with some enzymes secreted by microorganisms found in the soil. We have identified a few structural files of such enzymes in the Protein Data Bank (PDB) [38]: alcohol dehydrogenases from Clostridium beijerinckii (PDB ID 1KEV), urease from Bacillus pasteurii (PDB ID 3UBP), phosphatase F from Bacillus subtilis (PDB ID 4I9C), and protease from Serratia marcescens (PDB ID 1SMP). The Chimera software [39] has been utilized for preparing the considered structures for molecular docking and for the analysis of docking results. We have considered only one chain for every enzyme, the ligands that are present in the crystallographic structure (excepting ions) have been removed, hydrogens and charges have been added. The structural file of S-metolachlor has been extracted from the PubChem database [40]. Molecular docking study has been implemented under SwissDock web server [41] that is based on EADock algorithm [42]. A blind, accurate and rigid docking has been considered.

Proteins with similar sequences frequently have similar structures and the same biological functions. Basic Local Alignment Search Tool (BLAST) [43] has been used to identify other enzymes that may be also affected by S-metolachlor. This tool compares the query sequence with sequences of various proteins in sequence database, measures the sequences similarity and calculates the statistical significance. We have only considered the sequences illustrating high sequence similarity, i.e., higher than $70 \%$ [44].

\section{Results}

\subsection{Assessment of the Enzymatic Activities}

Mean values for the measured enzymatic activities after 7, 14 and 21 days of incubation respectively are presented in Table 2 .

The data presented in Table 2 reveal that mean values for the measured enzymatic activities ranged: (i) for DA, between 0.16 for the $\mathrm{V} 5$ variant at 21 days and 3.91 for control (M) at 7 days; (ii) for UA, between 0.43 for the V5 variant at 7 days and 2.32 for control at 21 days; (iii) for PA, between 0.01 for control at 7 days and 0.19 for control at 21 days; (iv) for PhA, between 1.37 for the V5 variant at 7 days and 2.56 for control at 7 days. The $\log 10$-transformed data for these variables were normally distributed $(p \geq 0.105)$. The tests for homogeneity of variance were not significant for DA, UA and PA $(p \geq 0.170)$, indicating that this assumption underlying the application of the two-way ANOVA was met for both variables. However, PhA did not meet this assumption $(p<0.001)$. 
Table 2. The mean levels for dehydrogenase (DA), urease (UA), protease (PA) and phosphatase (PhA) activity for every experimental variant at each time point. The meaning of the experimental variants (M, V1-V5) is specified in Table 1.

\begin{tabular}{cccccc}
\hline Day & Dose (Variant) & DA & UA & PA & PhA \\
\hline 7 & $0 \mathrm{~g}(\mathrm{M})$ & $3.91 \pm 0.34$ & $1.11 \pm 0.22$ & $0.01 \pm 0.01$ & $2.56 \pm 0.36$ \\
7 & $1 \mathrm{~g}$ (V1) & $2.55 \pm 0.28$ & $0.65 \pm 0.11$ & $0.07 \pm 0.03^{* * *}$ & $2.27 \pm 0.27$ \\
7 & $3 \mathrm{~g}$ (V2) & $2.43 \pm 0.17$ & $0.62 \pm 0.11$ & $0.04 \pm 0.02^{* * *}$ & $2.16 \pm 0.18$ \\
7 & $6 \mathrm{~g}$ (V3) & $0.24 \pm 0.12^{* * *}$ & $0.59 \pm 0.19$ & $0.09 \pm 0.01^{* * *}$ & $1.95 \pm 0.25$ \\
7 & $9 \mathrm{~g}$ (V4) & $0.21 \pm 0.08^{* * *}$ & $0.49 \pm 0.07$ & $0.07 \pm 0.02^{* * *}$ & $1.88 \pm 0.19$ \\
7 & $12 \mathrm{~g}$ (V5) & $0.18 \pm 0.05^{* * *}$ & $0.43 \pm 0.16$ & $0.03 \pm 0.01^{* * *}$ & $1.38 \pm 0.26$ \\
14 & $0 \mathrm{~g}$ (M) & $3.07 \pm 0.23$ & $1.13 \pm 0.24$ & $0.12 \pm 0.03$ & $1.90 \pm 0.30$ \\
14 & $1 \mathrm{~g}$ (V1) & $1.50 \pm 0.34$ & $0.83 \pm 0.19$ & $0.08 \pm 0.01^{* * *}$ & $2.04 \pm 0.17$ \\
14 & $3 \mathrm{~g}$ (V2) & $1.01 \pm 0.17^{* *}$ & $0.82 \pm 0.16$ & $0.09 \pm 0.02^{* * *}$ & $2.08 \pm 0.14$ \\
14 & $6 \mathrm{~g}$ (V3) & $0.21 \pm 0.09^{* * *}$ & $0.71 \pm 0.11$ & $0.07 \pm 0.00^{* * *}$ & $1.99 \pm 0.23$ \\
14 & $9 \mathrm{~g}$ (V4) & $0.19 \pm 0.10^{* * *}$ & $0.60 \pm 0.18$ & $0.05 \pm 0.01^{* * *}$ & $1.86 \pm 0.18$ \\
14 & $12 \mathrm{~g}$ (V5) & $0.18 \pm 0.04^{* * *}$ & $0.66 \pm 0.13$ & $0.04 \pm 0.01^{* * *}$ & $1.79 \pm 0.26$ \\
21 & $0 \mathrm{~g}$ (M) & $2.37 \pm 0.23$ & $2.33 \pm 0.24$ & $0.19 \pm 0.05$ & $2.44 \pm 0.19$ \\
21 & $1 \mathrm{~g}$ (V1) & $0.44 \pm 0.27^{* * *}$ & $0.96 \pm 0.16$ & $0.12 \pm 0.03^{* * *}$ & $2.02 \pm 0.36$ \\
21 & $3 \mathrm{~g}$ (V2) & $0.41 \pm 0.13^{* * *}$ & $0.78 \pm 0.11$ & $0.10 \pm 0.04^{* * *}$ & $2.11 \pm 0.29$ \\
21 & $6 \mathrm{~g}$ (V3) & $0.30 \pm 0.12^{* * *}$ & $0.75 \pm 0.09$ & $0.10 \pm 0.01^{* * *}$ & $1.92 \pm 0.32$ \\
21 & $9 \mathrm{~g}$ (V4) & $0.18 \pm 0.08^{* * *}$ & $0.90 \pm 0.33$ & $0.08 \pm 0.03^{* * *}$ & $1.89 \pm 0.28$ \\
\hline
\end{tabular}

Marked boxes $\left(^{*}\right)$ indicate significant differences as compared to the reference group (Tukey's HSD test, ${ }^{* * *} p<0.001,{ }^{* *} p<0.01$ ).

A significant effect of the herbicide dose on the DA was observed $(F(5,53)=104.41$, $p<0.001, \eta^{2}=0.804$ ). Post hoc analyses with the Tukey's HSD procedure showed a significant dose-dependent decrease in the measured values (Figure 2a). The exposure duration effect on the DA was also significant $\left(F(2,53)=19.61, p<0.001, \eta^{2}=0.059\right)$ (Figure 2b) but the relative impact of this variable was more than 15-fold lower as compared to that of herbicide dose. There was a significant time-dependent decrease in the measured values for DA, as shown by post hoc analyses (Figure $2 b$ ). The meaning of this effect was qualified, however, by a significant outcome of the interaction between the herbicide dose and the exposure duration $\left(\mathrm{F}(10,53)=5.14, p<0.001, \eta^{2}=0.076\right)$. That is, the main effect of exposure duration depends on the level of applied herbicide. After 7 days of exposure (Table 2), the measured values for the DA levels were significantly lower in the V3, V4, V5 treatment groups compared to the unexposed control (M). At 14 days (Table 2), the same trend was detected. This trend of decreasing of the DA values was even more noticeable after 21 days (Figure $2 b$ ), when all treatments were associated with significantly reduced DA levels relative to the reference group.

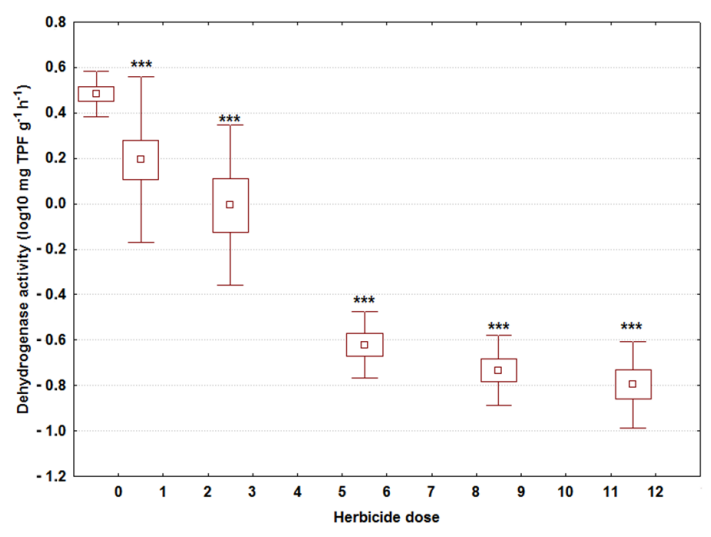

(a)

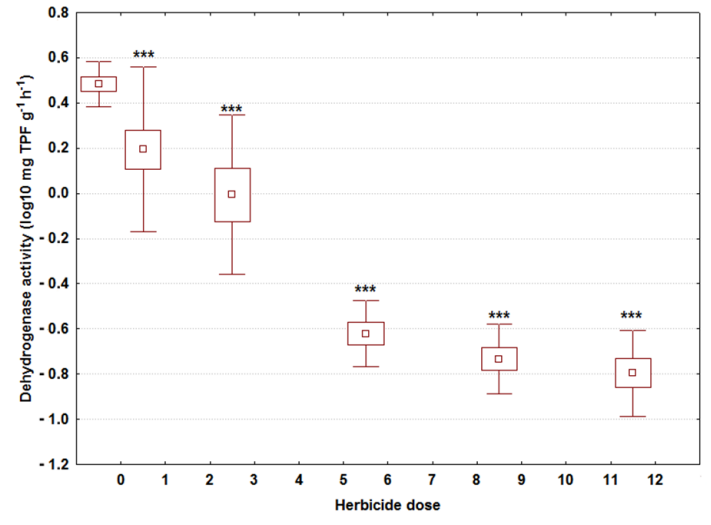

(b)

Figure 2. Cont. 


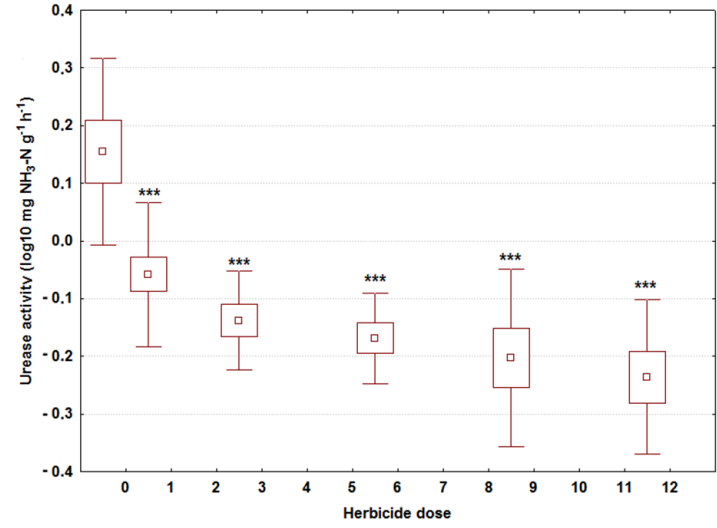

(c)

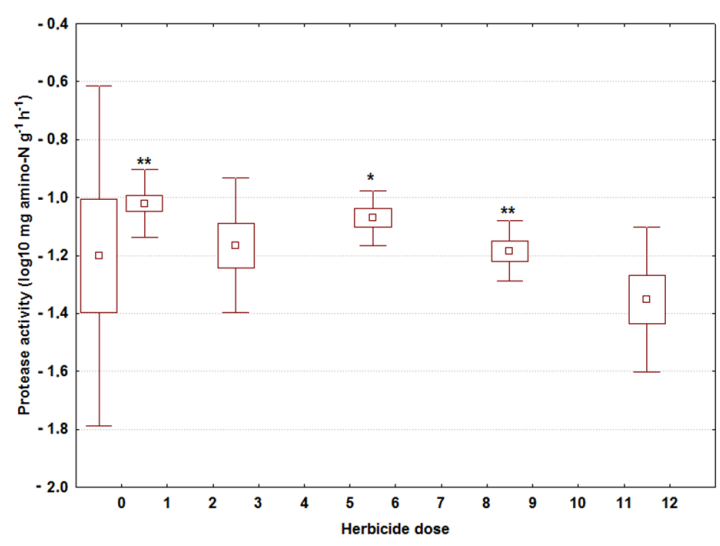

(e)

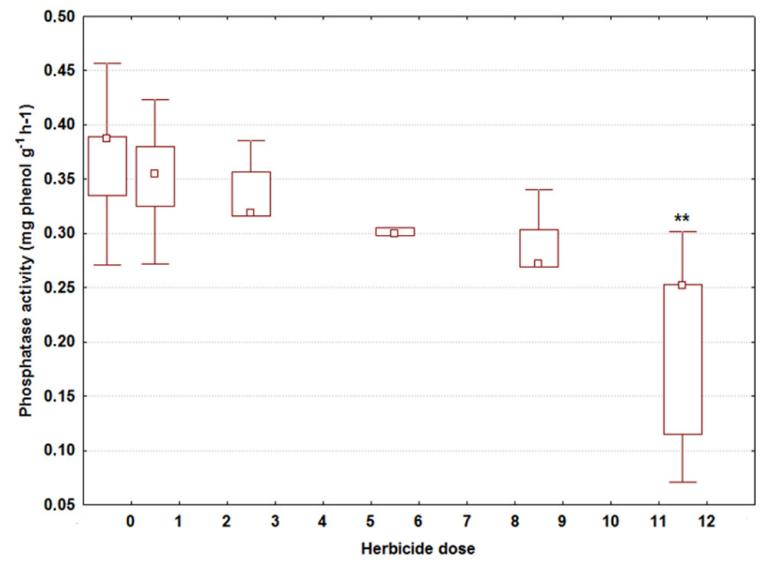

(g)

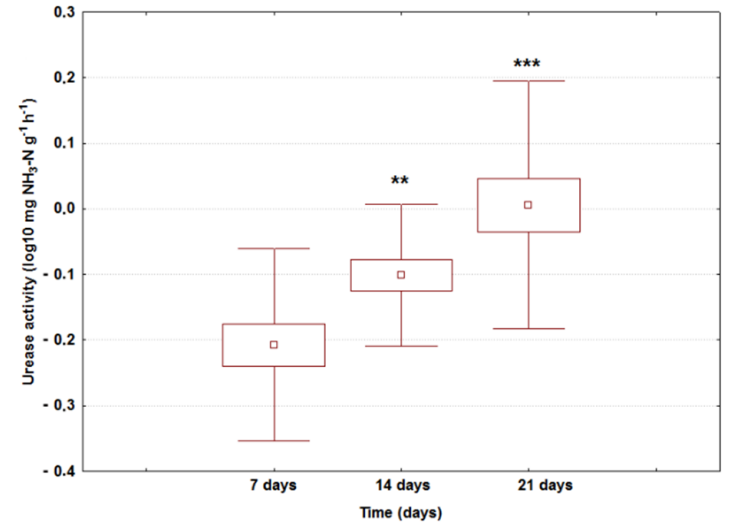

(d)

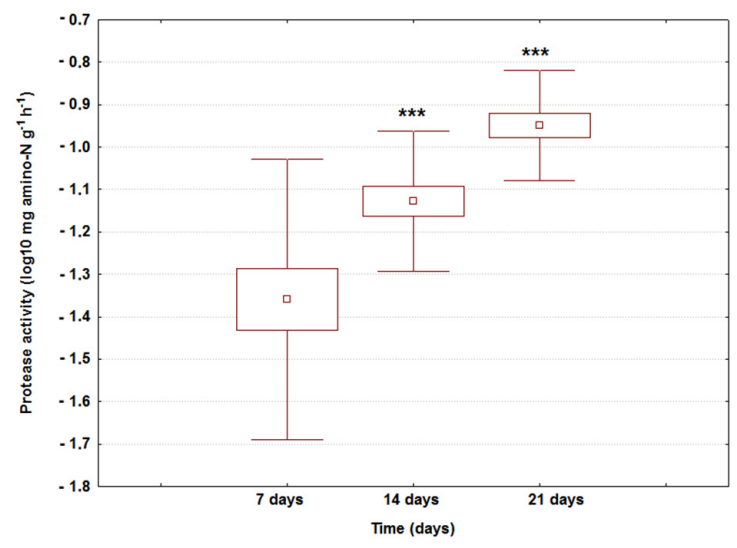

(f)

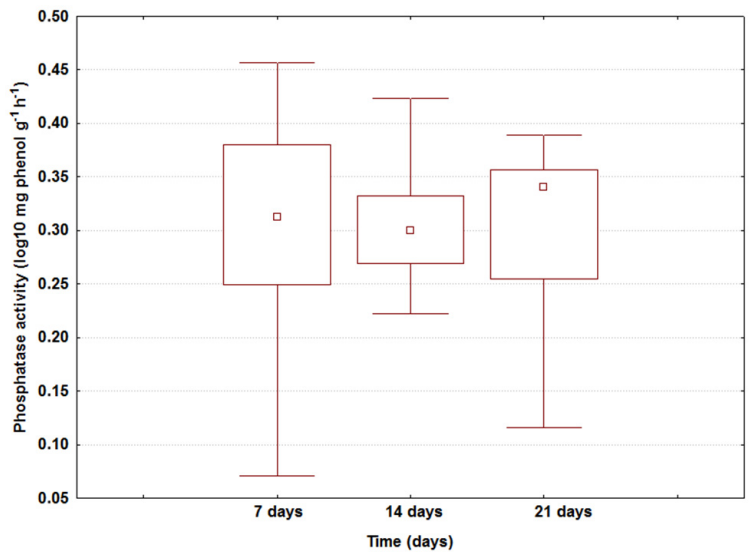

(h)

Figure 2. Evolution of enzymatic activities depending on the applied dose of S-metolachlor and on incubation time: dehydrogenase activity dependence on the dose of S-metolachlor (a) and on the incubation time (b); urease activity dependence on the dose of S-metolachlor (c) and on the incubation time (d); protease activity dependence on the dose of S-metolachlor (e) and on the incubation time (f); phosphatase activity dependence the dose of S-metolachlor (g) and on the incubation time (h). Parametric statistics was used to analyze data related to dehydrogenase activity, urease activity and protease activity, whereas nonparametric statistics was used for data related to phosphatase activity. The measured values for dehydrogenase activity, urease activity and protease activity are shown on $\log _{10}$ scale as mean (point) with one standard error (box) and one standard deviation (error bar). The measured values for phosphatase activity are shown on $\log _{10}$ scale as median (point) with lower and upper quartiles (box) and minimum and maximum values (error bar). Marked boxes $\left(^{*}\right)$ indicate significant differences as compared to the reference group (for dehydrogenase activity, urease activity and protease activity: Tukey's HSD test, ${ }^{* * *} p<0.001,{ }^{* *} p<0.01,{ }^{*} p<0.05$; for phosphatase activity: Dunn's test, ${ }^{* * *} p<0.001,{ }^{* *} p<0.01,{ }^{*} p<0.05$ ). 
There was a significant main effect of the herbicide dose on the UA $(F(5,53)=26.26$, $\left.p<0.001, \eta^{2}=0.546\right)$ Application of post hoc pairwise comparisons revealed a significant dose-dependent decrease in UA levels (Figure 2c). The measured values of the UA increased significantly with time (Figure 2d). The main effect of exposure duration on UA was also significant $\left(F(2,53)=25.66, p<0.001, \eta^{2}=0.211\right)$, with the relative impact of this variable being two-fold lower than that observed for the herbicide dose. When compared to the first time point, the measured values increased significantly with time (Figure 2d). The interaction between herbicide dose and the exposure duration was not statistically significant $\left(\mathrm{F}(10,53)=1.91, p=0.072, \eta^{2}=0.072\right)$.

Herbicide dose exerted a significant effect on the PA values $(F(5,53)=15.67, p<0.001$, $\left.\eta^{2}=0.114\right)$. Post hoc analyses indicated an irregular pattern of the PA variation, with the measured values increasing significantly for the V1 treatment group, returning to normal for the V2 variant, increasing again significantly for the V3 variant before showing an evident trend of decrease with the dose (Figure 2e). There was a significant time-dependent increase in the measured values for the PA, as shown by post hoc analyses (Figure 2f) $\left(\mathrm{F}(2,53)=131.11, p<0.001, \eta^{2}=0.384\right)$. The main effect of exposure duration on PA was significant $\left(\mathrm{F}(2,53)=131.11, p<0.001, \eta^{2}=0.384\right)$. In addition, the relative impact of this variable was more than three-fold higher as compared to that of the herbicide dose. There was a significant time-dependent increase in the measured values for PA, as shown by post hoc analyses with Tukey's HSD tests (Figure 2f). The meaning of this effect was also qualified by a significant outcome of the interaction between the herbicide dose and the exposure duration $\left(F(10,53)=30.37, p<0.001, \eta^{2}=0.021\right)$. This implies that the main effect of exposure duration depends on the level of applied herbicide. After 7 days of exposure (Table 2), the measured values for the PA were significantly higher for all treatment groups compared to the unexposed controls. After 14 days (Table 2), surprisingly, an inverse trend was noted, with the measured values decreasing in a dose-dependent manner. This trend was further maintained at 21 days (Table 2).

Application of Kruskall-Wallis one-way analysis of variance revealed a significant effect of the herbicide dose on the $\mathrm{PhA}$ values $(\mathrm{H}(5,54)=18.83, p=0.021)$ that decreased with the dose, with significantly lower PhA level compared to controls being identified for the V5 variant (Figure 2g). In contrast, there was not significant differences between the median PhA values at different time points $(\mathrm{H}(2,63)=0.91, p=0.635)$ (Figure $2 \mathrm{~h}$ ).

When compared to control variants after 7 days, the measured values were: (i) similar after both 14 days and 21 days for the DA ( $p \geq 0.943$ ); (ii) similar after 14 days ( $p=0.998$ ), but significantly higher after 21 days for the UA ( $p=0.003$ ); (iii) significantly higher after both 14 and 21 days for the PA $(p<0.001)$; (iv) significantly higher after both 14 and 21 days for the PhA $(p<0.001)$. Spearman correlation analysis revealed significant and strong inverse relationships between the herbicide dose and the DA, UA and PhA, but not with the PA.

\subsection{Correlation between the Enzymatic Activities and Physicochemical Properties of the Soil}

There were significant correlations between the enzymatic activities analyzed and the soil physicochemical parameters (Table 3 ).

Thus, moderate and strong positive correlations were identified between the DA, $\mathrm{UA}$ and $\mathrm{PhA}$ and the soil $\mathrm{pH}$, moisture, organic matter, nitrogen level and available phosphorus. In contrast, the PA correlated moderately negative with the soil nitrogen content, but moderately positive with the soil $\mathrm{pH}$. 
Table 3. Correlations between the enzymatic activities, the herbicide dose and the soil physicochemical parameters: DAdehydrogenase activity, UA—urease activity, PA—protease activity, PhA—phosphatase activity, EC—electric conductivity, OM-organic matter content.

\begin{tabular}{|c|c|c|c|c|c|c|c|c|c|c|c|c|}
\hline Herbicide Dose & & & & & & & & & & & & \\
\hline DA & -0.914 * & & & & & & & & & & & \\
\hline UA & -0.735 * & $0.486 *$ & & & & & & & & & & \\
\hline PA & -0.429 & 0.142 & $0.658 *$ & & & & & & & & & \\
\hline $\mathrm{PhA}$ & -0.873 * & $0.897 *$ & $0.471 *$ & 0.264 & & & & & & & & \\
\hline $\mathrm{pH}$ & -0.863 * & $0.717^{*}$ & $0.880 *$ & $0.552 *$ & 0.678 * & & & & & & & \\
\hline $\mathrm{t}\left({ }^{\circ} \mathrm{C}\right)$ & 0.001 & -0.077 & 0.034 & 0.315 & -0.358 & -0.402 & & & & & & \\
\hline $\mathrm{EC}$ & -0.061 & -0.070 & 0.306 & 0.386 & -0.170 & 0.234 & 0.383 & & & & & \\
\hline Soil moisture & -0.567 * & $0.442 *$ & $0.589 *$ & 0.283 & $0.467 *$ & $0.539 *$ & -0.400 & 0.194 & & & & \\
\hline $\mathrm{OM}(\mathrm{mg} / \mathrm{g})$ & -0.624 * & $0.534 *$ & 0.370 & 0.202 & $0.595 *$ & $0.514 *$ & -0.282 & -0.320 & 0.267 & & & \\
\hline $\mathrm{NO}_{3}-\mathrm{N}(\mathrm{mg} / \mathrm{g})$ & $-0.602 *$ & 0.509 * & 0.510 * & 0.339 & 0.382 & 0.487 * & 0.298 & 0.262 & 0.283 & 0.146 & & \\
\hline $\mathrm{NH}_{4}-\mathrm{N}(\mathrm{mg} / \mathrm{kg})$ & -0.108 & 0.335 & -0.417 & $\underset{*}{-0.647}$ & 0.217 & -0.153 & -0.376 & -0.294 & -0.100 & 0.217 & -0.051 & \\
\hline $\begin{array}{c}\text { Available } \\
\text { phosphorus } \\
\text { (mg/kg) }\end{array}$ & $-0.806^{*}$ & 0.709 * & $0.544^{*}$ & 0.386 & 0.706 * & $0.716^{*}$ & 0.043 & 0.147 & 0.232 & 0.478 * & $0.666^{*}$ & 0.138 \\
\hline
\end{tabular}

Marked boxes $(*)$ indicate significant correlations $(p<0.05)$.

\subsection{Computational Approach}

The molecular docking study results gave good correlations with the experimental data and reveal that S-metolachlor is able to bind to the active sites of dehydrogenase, phosphatase and protease. The herbicide does not bind to the catalytic cavity of urease. Figure 3 illustrates the most favorable binding modes of S-metolachlor to dehydrogenase (a), phosphatase (b) and protease (c), respectively all the binding modes of S-metolachlor to urease (d). The values of the interaction energies between S-metolachlor and investigated enzymes and corresponding to the most favorable binding modes are also illustrated in Figure 3. The BLAST analysis is presented in Table 4.

Table 4. Enzymes illustrating high sequence similarity with those considered in molecular docking study and that are potentially affected by the presence of S-metolachlor.

\begin{tabular}{|c|c|}
\hline Enzyme & Sequences Identity with Other Enzymes \\
\hline $\begin{array}{l}\text { alcohol dehydrogenases from Clostridium } \\
\text { beijerinckii }\end{array}$ & $\begin{array}{c}71.2 \text { to } 73.4 \% \text { with alcohol dehydrogenases } \\
\text { from Desulfotomaculum sp. } \\
71.5 \text { to } 93.4 \% \text { alcohol dehydrogenases from } \\
\text { Clostridium sp. }\end{array}$ \\
\hline phosphatase F from Bacillus subtilis & $\begin{array}{l}\text { Low sequence identity (up to } 57.5 \% \text { ) with } \\
\text { phosphatases F from Bacillus sp. }\end{array}$ \\
\hline protease from Serratia marcescens & 82.8 to $98.2 \%$ proteases from Seratia sp. \\
\hline urease from Bacillus pasteurii & 70 to $98.2 \%$ with ureases from Bacillus sp. \\
\hline
\end{tabular}

Enzymes that were identified as having high sequence similarity with those considered in the molecular docking study are usually secreted by organisms belonging to the same species. S-metolachlor may bind to and inhibit dehydrogenases from numerous microorganisms belonging to Clostridium sp. and from a few members of Desulfotomaculum sp., and proteases belonging to numerus members of Serratia sp. There is a low sequence similarity between phosphatase $\mathrm{F}$ from Bacillus subtilis and phosphatases from other members of Bacillus sp. and these phosphatases may not be affected by the presence of S-metolachlor. Ureases from Bacillus sp. share high similarity of sequences and, consequently, S-metolachlor may have an allosteric inhibition effect against these enzymes. 


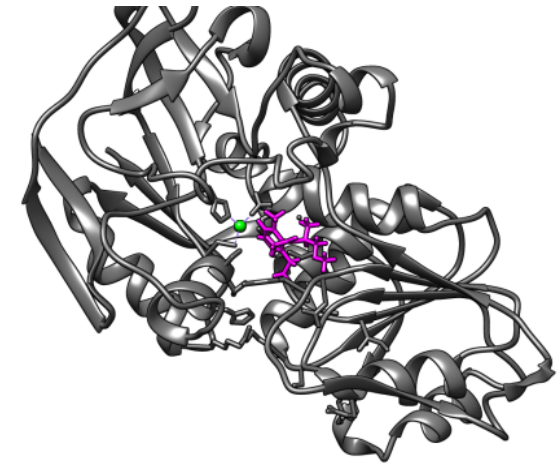

$\Delta \mathrm{G}=-7.17 \mathrm{kcal} / \mathrm{mol}$

(a)

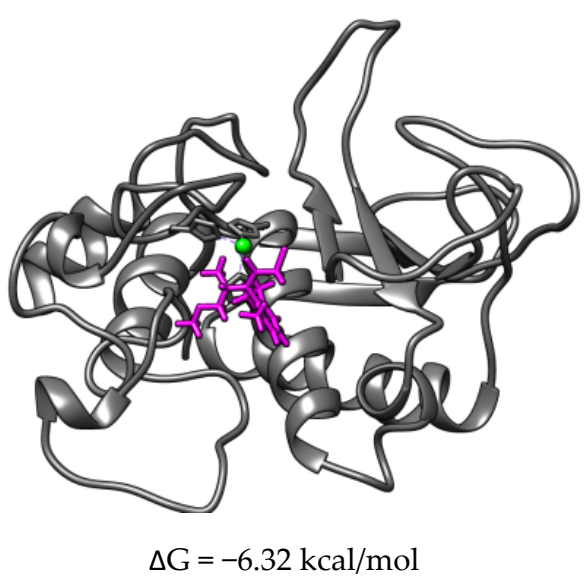

(c)

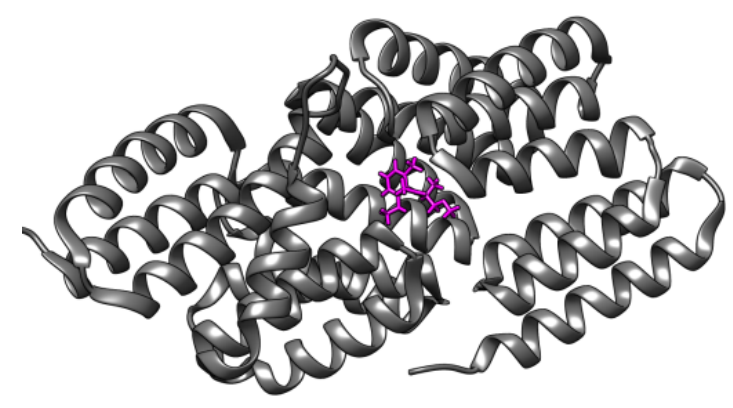

$\Delta \mathrm{G}=-6.72 \mathrm{kcal} / \mathrm{mol}$

(b)

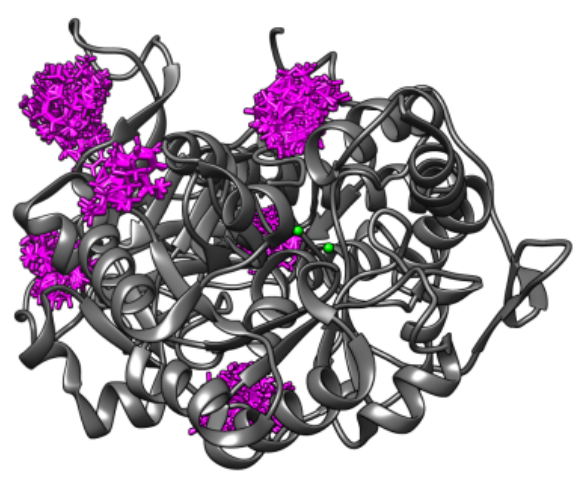

S-metolachlor does not bind to the active site

(d)

Figure 3. Results illustrating the most favorable binding modes of S-metolachlor to the active sites of dehydrogenase (a), phosphatase (b) and protease (c), respectively all the binding modes for S-metolachlor to urease (d). Enzymes are illustrated as dim grey ribbon, S-metolachlor is illustrated as magenta sticks, zinc (in the case of dehydrogenase and protease) and nickel (in the case of urease) ions are illustrated as green spheres. $\Delta \mathrm{G}$ represents the interaction energy between S-metolachlor and investigated enzymes.

\section{Discussion}

Dehydrogenase activity (DA) is considered the most efficient indicator of the general condition of the soil, because dehydrogenases are present in all living cells [45]. Furthermore, among all the enzymatic activities that are determined when analyzing the effects of the herbicides on the communities of microorganisms found in soil, the DA has been shown to be the most sensitive to the application of herbicides [6,17]. Data obtained in the present study reveal that S-metholachlor is able to bind to the catalytic cavity of dehydrogenase and that the DA strongly decreases with increasing the dose of S-metolachlor. S-metholachlor may affect dehydrogenases secreted by numerous soil bacteria belonging to genus Clostridium sp. and by a few members of Desulfotomaculum sp. These results are in good agreement with those obtained in other study revealing the decrease by $10-30 \%$ of the average values of DA in soils treated with S-metolachlor compared to those recorded in untreated soils [22]. There also was a decrease of the DA up to $83 \%$ when using a mixture of herbicides containing terbuthylazine, mesotrione and S-metolachlor [25]. The study made by Wołejko and co-workers revealed an increase in the DA for the first 28 days after application of S-metolachlor, followed by a decrease in DA by $12-70 \%$ that was maintained for the 85 days of incubation [22]. This behavior was explained by the fact that the herbicide, together with its metabolic products, can stimulate the DA in the first period of 
incubation. For a longer period of time, the dissipation of the active substance conducted to the decrease in the DA [22].

Urease is the hydrolytic enzyme that causes the breakdown of urea and has a major role in the nitrogen cycle in the soil. Determining the urease activity (UA) in soil is important for the better understanding of the process of mineralization of nitrogen compounds, for assessing the effects of the application of inorganic fertilizers, for understanding soil management systems and especially the relationship of enzymatic activity with agricultural practices [46]. The survival of ammonium fertilizers in agricultural soils depends on the activity of this enzyme, fertilization practices having significant effects on the urease activity in the soil [47]. Our molecular docking study emphasizes that S-metolachlor is able to bind to various cavities of urease, but not to its catalytic cavity. It does not exclude the inhibitory effect of S-metolachlor against urease as there can be an allosteric inhibition due to binding of herbicide to another cavity on the enzyme surface. This study illustrated a significant dose-dependent decrease of the UA when S-metolachlor was applied to the soil samples. These findings are in accordance with published data revealing the decreases of $89 \%$ in UA when a complex of 3 herbicides (terbuthylazine, mesotrione and S-metolachlor) has been applied [25]. Analyzing the values recorded for the UA in relation to the incubation time, the outcomes of this study reveal that the UA increases with increasing incubation time. This is in discordance with the results of other studies revealing significant decreases in UA with increasing incubation time $[46,48]$. This disagreement can be explained by the fact that ureases enclosed in living or dead microorganisms, in association with/or in cellular wastes are not taken into consideration during the experiments, or by the influence of the type of the soil.

Acidic and alkaline phosphatases play an important role in the phosphorus circuit in the soil, being involved in the solubilization of insoluble phosphate monoesters [49]. Phosphatase activity (PhA) is essential at the soil level as it ensures the decomposition of phosphate-containing organic substrates and their transformation into inorganic forms by hydrolysis [50]. Along with other enzymatic activities in the soil, the PhA is used as a bioindicator for monitoring the biological quality of the soil after the application of pesticides [51-53]. The outcomes of the present study emphasizes that S-metolachlor is also able to bind to the catalytic site of phosphatase and there is a statistically significant decrease in the PhA in the soil samples treated with S-metolachlor, the decrease being stronger for higher doses of herbicide. The decrease in the PhA dependent on the applied dose and on the incubation period has been also reported in soil samples contaminated with treflan 460 EC [54], triflurotox 250 CE [55], and acetamipyride [56]. The application of S-metolachlor in combination with two other herbicides (terbuthylazine and mesotrione) also led to a $27 \%$ decrease in the activity of acid phosphatase and a $57 \%$ decrease the activity of alkaline phosphatase, the effect being correlated with the applied dose [25]. Other study showed that there were no statistically significant differences in the activity of phosphomonoesterases in the soil samples treated with S-metolachlor, but the activity of acid phosphatase increased over the time of incubation [22]. The increase in the PhA in the soil caused by application of Aurora 40 WG herbicide has been also registered [57].

Protease is an enzyme involved in the initial hydrolysis of organic compounds with nitrogen to simple amino acids, the first important step in the nitrogen cycle. Proteases are widely distributed in soils and are involved in the circulation of organic matter [58]. Soil protease activity (PA) is strongly influenced by the concentration of available protein compounds, the amount of ammonium nitrate, as well as the presence or absence of proteolytic microorganisms [59]. Our data reveal the ability of S-metolachlor to bind to the active site of protease, a significant decrease of the PA with increasing the dose of the applied herbicide and a significant increase over time in the PA values recorded at the level of all soil samples from the treated experimental variants compared to the untreated soil. Following the evolution of the PA when applying other herbicides (carbofuran, paraquat), statistically significant variations were found at the level of the treated soils compared to the control ones depending on the applied dose and the incubation period. After 7 and 
14 days of incubation the effect was the decrease the protease activity, but there was and increases the in protease activity after 21 days of incubation [46].

Within the present study, the DA, UA and PhA revealed positive correlation with the following properties of the soil: the $\mathrm{pH}$, moisture, organic matter, nitrogen level and available phosphorus in the soil. The PA also correlated positive with the soil $\mathrm{pH}$, but correlated moderately negative with the soil nitrogen content. It is widely accepted that the soil physicochemical parameters have a great impact on the activity of enzymes found in the soil. Quite similar results as those presented in this study have been reported in the literature. The positive effect of the soil $\mathrm{pH}$, organic matter and total nitrogen content on the activity of the soil enzymes was also registered on the activity of the soil enzymes, in particular for dehydrogenase, phosphatase and urease $[60,61]$. These findings confirm the importance of the type of soil for the activity of soil enzymes.

\section{Conclusions}

The outcomes of this study reveal a significant inhibition effect of S-metolachlor against dehydrogenase, protease, phosphatase and urease, the decreases in the activities of these enzymes being dose-dependent. The activities of dehydrogenase and phosphatase decrease for the entire period of incubation and it illustrates that more than 21 days are necessary to recover the activities of these enzymes in soil treated with S-metolachlor. The activity of protease increases after 14 days of incubation and the activity of urease increases after 7 days of incubation. Molecular docking study emphasizes the ability of the herbicide to bind to the catalytic cavity of dehydrogenase, protease and phosphatase, the highest binding affinity being registered for dehydrogenase, the enzyme illustrating the most important decrease in the activity. Furthermore, there were significant correlations between the analyzed enzymatic activities and some physicochemical parameters of the soil. Positive correlations were identified for the $\mathrm{DA}, \mathrm{UA}$ and $\mathrm{PhA}$ with the soil $\mathrm{pH}$, moisture, organic matter, nitrogen level and available phosphorus. By contrary, PA registered a negative correlation with the soil nitrogen, and a positive correlation with the soil $\mathrm{pH}$.

Author Contributions: All authors designed the study, analyzed and interpreted the results; M.N.F. performed biological experiments and collected data; I.V.C. performed statistical analysis; D.L.R., A.I. performed the bioinformatics study and collected data; M.N.F. and A.I. edited the manuscript. All authors have read and agreed to the published version of the manuscript.

Funding: This research received no external funding.

Institutional Review Board Statement: Not applicable.

Informed Consent Statement: Not applicable.

Data Availability Statement: Not applicable.

Conflicts of Interest: The authors declare no conflict of interest.

\section{References}

1. Ayansina, A.D.; Amusan, O.A. Effect of Higher Concentrations of Herbicides on Bacterial Populations in Tropical Soil. Unique Res. J. Agric. Sci. 2013, 1, 001-005. Available online: http:/ / www.uniqueresearchjournals.org/URJAS (accessed on 15 January 2021).

2. Baćmaga, M.; Kucharski, J.; Wyszkowska, J.; Borowik, A.; Tomkiel, M. Responses of microorganisms and enzymes to soil contamination with metazachlor. Environ. Earth Sci. 2014, 72, 2251-2262. [CrossRef]

3. Marzaioli, R.; D'Ascoli, R.; de Pascale, R.A.; Rutigliano, F.A. Soil quality in a Mediterranean area of Southern Italy as related to different land use types. Appl. Soil Ecol. 2010, 44, 205-212. [CrossRef]

4. Muñoz-Leoz, B.; Garbisu, C.; Charcosset, J.-Y.; Sanchez-Pérez, J.-M.; Antigüedad, I.; Ruiz-Romera, E. Non-target effects of three formulated pesticides on microbially-mediated processes in a clay-loam soil. Sci. Total. Environ. 2013, 449, 345-354. [CrossRef]

5. Baćmaga, M.; Kucharski, J.; Wyszkowska, J.; Borowik, A.; Tomkiel, M. Response of fungi, $\beta$-glucosidase and arylsulfatase to soil contamination by Alister Grande 190 OD, Fuego 500 SC and Lumax 357.5 SE herbicides. Pol. J. Environ. Stud. 2014, 23, 19-25. [CrossRef] 
6. Baćmaga, M.; Borowik, A.; Kucharski, J.; Tomkiel, M.; Wyszkowska, J. Microbial and enzymatic activity of soil contaminated with a mixture of diflufenican + mesosulfuron-methyl + iodosulfuron-methyl-sodium. Environ. Sci. Pollut. Res. 2015, 22, 643-656. [CrossRef] [PubMed]

7. Hussain, S.; Siddique, T.; Saleem, M.; Arshad, M.; Khalid, A. Chapter 5 Impact of Pesticides on Soil Microbial Diversity, Enzymes, and Biochemical Reactions. Adv. Agron. 2009, 102, 159-200. [CrossRef]

8. Filimon, M.N.; Borozan, A.B.; Bordean, D.M.; Popescu, R.; Gotia, S.R.; Verdes, D.; Sinitean, A. Sulphonylureic herbicidal risk in the detection of soil fungi communities. Afr. J. Microbiol. Res. 2011, 5, 5507-5511. [CrossRef]

9. Filimon, M.N.; Voia, O.S.; Popescu, R.; Dumitrescu, G.; Petculescu-Ciochina, L.; Mituletu, M.; Vlad, D.C. The effect of some insecticides on soil microorganisms based on enzymatic and bacteriological analyses. Rom. Biotech. Lett. 2015, 20, 10439-10447.

10. Cai, Z.; Li, S.; Zhang, W.; Ma, J.; Wang, J.; Cai, J.; Yang, G. Effects of the novel pyrimidynyloxybenzoic herbicide ZJ0273 on enzyme activities, microorganisms and its degradation in Chinese soils. Environ. Sci. Pollut. Res. 2014, 22, 4425-4433. [CrossRef]

11. Filimon, M.N.; Voia, S.O.; Vladoiu, D.L.; Isvoran, A.; Ostafe, V. Temperature dependent effect of difenoconazole on enzymatic activity from the soil. J. Serb. Chem. Soc. 2015, 80, 1127-1137. [CrossRef]

12. Kucharski, J.; Tomkiel, M.; Baćmaga, M.; Borowik, A.; Wyszkowska, J. Enzyme activity and microorganisms diversity in soil contaminated with the Boreal 58 WG herbicide. J. Environ. Sci. Health B 2016, 51, 446-454. [CrossRef] [PubMed]

13. Floch, C.; Chevremont, A.-C.; Joanico, K.; Capowiez, Y.; Criquet, S. Indicators of pesticide contamination: Soil enzyme compared to functional diversity of bacterial communities via Biolog ${ }^{\circledR}$ Ecoplates. Eur. J. Soil Biol. 2011, 47, 256-263. [CrossRef]

14. Filimon, M.N.; Voia, O.S.; Popescu, R.; Bordean, D.-M.; Vladoiu, D.L.; Mituletu, M.; Ostafe, V. The effect of chlorsulfurone and MCPB-Na on the enzymatic activity of microorganisms. J. Serb. Chem. Soc. 2014, 79, 1075-1084. [CrossRef]

15. Riah, W.; Laval, K.; Laroche-Ajzenberg, E.; Mougin, C.; Latour, X.; Trinsoutrot-Gattin, I. Effects of pesticides on soil enzymatic activities: General trends. Environ. Chem. Lett. 2014, 12, 257-273. [CrossRef]

16. Xiong, D.; Gao, Z.; Fu, B.; Sun, H.; Tian, S.; Xiao, Y.; Qin, Z. Effect of pyrimorph on soil enzymatic activities and respiration. Eur. J. Soil Biol. 2013, 56, 44-48. [CrossRef]

17. Long, Y.H.; Li, R.T.; Wu, X.M. Degradation of S-metolachlor in soil as affected by environmental factors. J. Soil Sci. Plant. Nutr. 2014, 14, 189-198. Available online: https://scielo.conicyt.cl/pdf/jsspn/v14n1/aop1514.pdf (accessed on 11 January 2021). [CrossRef]

18. Filimon, M.N.; Popescu, R.; Verdes, D.; Dumitrescu, G.; Voia, O.S.; Ahmadi, M.; Dronca, D. The Effects of Difenoconazole Treatment on Microorganism from Soil. Rev. Chim. 2018, 69, 1129-1133. [CrossRef]

19. Zhang, C.; Liu, X.; Dong, F.; Xu, J.; Zheng, Y.; Li, J. Soil microbial communities response to herbicide 2,4-dichlorophenoxyacetic acid butyl ester. Eur. J. Soil Biol. 2010, 46, 175-180. [CrossRef]

20. Wu, X.M.; Li, M.; Long, Y.H.; Liu, R.X.; Yu, Y.L.; Fang, H.; Li, S.N. Effects of adsorption on degradation and bioavailability of metolachlor in soil. J. Soil. Sci. Plant. Nutr. 2011, 11, 83-97. [CrossRef]

21. Zemolin, C.R.; Avila, L.A.; Cassol, G.V.; Massey, J.H.; Camargo, E.R. Environmental fate of S-Metolachlor: A review. Planta Daninha Viçosa-MG 2014, 32, 655-664. [CrossRef]

22. Wołejko, E.; Kaczyński, P.; Łozowicka, B.; Wydro, U.; Borusiewicz, A.; Hrynko, I.; Konecki, R.; Snarska, K.; Dec, D.; Malinowski, P. Dissipation of S-metolachlor in plant and soil and effect on enzymatic activities. Environ. Monit. Assess. 2017, 189, 355. [CrossRef]

23. Si, Y.; Takagi, K.; Iwasaki, A.; Zhou, D. Adsorption, desorption and dissipation of metolachlor in surface and subsurface soils. Pest. Manag. Sci. 2009, 65, 956-962. [CrossRef] [PubMed]

24. Lipşa, F.D.; Ulea, E.; Chiriac, I.P.; Coroi, I.G. Effect of herbicide S-metolachlor on soil microorganisms. Lucr. Stiinţifice Ser. Agron. 2010, 53, 110-113. (In Romanian)

25. Borowik, A.; Wyszkowska, J.; Kucharski, J.; Baćmaga, M.; Tomkiel, M. Response of microorganisms and enzymes to soil contamination with a mixture of terbuthylazine, mesotrione, and S-metolachlor. Environ. Sci. Pollut. Res. 2017, 24, 1910-1925. [CrossRef]

26. Li, J.; Nie, M.; Powell, J.R.; Bissett, A.; Pendall, E. Soil physico-chemical properties are critical for predicting carbon storage and nutrient availability across Australia. Environ. Res. Lett. 2020, 15, 094088. [CrossRef]

27. Pub Chem. Data Base. Available online: https://pubchem.ncbi.nlm.nih.gov/compound/S-Metolachlor (accessed on 10 October 2020).

28. USEPA. Toxicology Chapter for Metolachlor/S-Metolachlor. 2001. Available online: https://archive.epa.gov/pesticides/ chemicalsearch/chemical/foia/web/pdf/108800/108800-2001-12-04a.pdf (accessed on 11 January 2021).

29. Bordean, D.M.; Borozan, A.B.; Cojocariu, L.; Moigradean, D.; Cojocariu, A.; Nica, D.; Pirvulescu, L.; Alda, S.; Horablaga, M. Seasonal variation in nutrient content of some leafy vegetables from Banat County, Romania. Rev. Agric. Rural Dev. 2003, 2, 170-174.

30. Gergen, I. Analiza Produselor Agroalimentare; Editura Eurostampa: Timisoara, Romania, 2004.

31. Baethgen, W.E.; Alley, M.M. A manual colorimetric procedure for measuring ammonium nitrogen in soil and plant Kjeldahl digests. Commun. Soil Sci. Plant. Anal. 1989, 20, 961-969. [CrossRef]

32. Uwah, E.I.; Abah, J.; Ndahi, N.P.; Ogugbuaja, V.O. Concentration levels of nitrate and nitrite in soils and some leafy vegetables obtained in Maiduguri, Nigeria. J. Appl. Sci. Environ. Sanit. 2009, 4, 233-244. 
33. Amponsah, D.; Etsey, G.; Nagai, H. Determination of Amount of Phosphate and Sulphate in Soil Samples from University of Cape Coast Farm. Int. J. Sci. Technol. Res. 2014, 3, 211-215. Available online: http://www.ijstr.org/final-print/july2014/Determination-OfAmount-Of-Phosphate-And-Sulphate-In-Soil-Samples-From-University-Of-Cape-Coast-Farm.pdf (accessed on 11 January 2021).

34. Schinner, F.; Öhlinger, R.; Kandeler, E.; Margesin, R. Methods in Soil Biology; Springer: Berlin/Heidelberg, Germany, 1996; pp. 241-243.

35. Hopkins, D.W.; Alef, K.; Nannipieri, P. Methods in Applied Soil Microbiology and Biochemistry. J. Appl. Ecol. 1996, 33, 178. [CrossRef]

36. Dick, R.P. Soil enzyme activities as integrative indicators of soil health. In Biological Indicators of Soil Health; Pankhurst, C.E., Doube, B.M., Gupta, V.V.S.R., Eds.; CAB International: Wallingford, UK, 1997; pp. 121-156.

37. Dragan-Bularda, M. Microbiologie Generala-Lucrari Practice; Editura Universitatii Babes-Bolyai: Cluj-Napoca, Romania, 2000; pp. 178-180, 189-191. (In Romanian)

38. Berman, H.M.; Westbrook, J.; Feng, Z.; Gilliland, G.; Bhat, T.N.; Weissig, H.; Shindyalov, I.N.; Bourne, P.E. The Protein Data Bank. Nucleic Acids Res. 2000, 28, 235-242. [CrossRef]

39. Pettersen, E.F.; Goddard, T.D.; Huang, C.C.; Couch, G.S.; Greenblatt, D.M.; Meng, E.C.; Ferrin, T.E. UCSF Chimera-A visualization system for exploratory research and analysis. J. Comput. Chem. 2004, 25, 1605-1612. [CrossRef]

40. Kim, S.; Chen, J.; Cheng, T.; Gindulyte, A.; He, J.; He, S.; Li, Q.; Shoemaker, B.A.; Thiessen, P.A.; Yu, B.; et al. PubChem 2019 update: Improved access to chemical data. Nucleic Acids Res. 2019, 47, D1102-D1109. [CrossRef] [PubMed]

41. Grosdidier, A.; Zoete, V.; Michielin, O. SwissDock, a protein-small molecule docking web service based on EADock DSS. Nucleic Acids Res. 2011, 39, W270-W277. [CrossRef] [PubMed]

42. Grosdidier, A.; Zoete, V.; Michielin, O. EADock: Docking of small molecules into protein active sites with a multiobjective evolutionary optimization. Proteins Struct. Funct. Bioinform. 2007, 67, 1010-1025. [CrossRef] [PubMed]

43. Altschul, S.F.; Madden, T.L.; Schäffer, A.A.; Zhang, J.; Zhang, Z.; Miller, W.; Lipman, D.J. Gapped BLAST and PSI-BLAST: A new generation of protein database search programs. Nucleic Acids Res. 1997, 25, 3389-3402. [CrossRef] [PubMed]

44. Pearson, W.R. An Introduction to Sequence Similarity ("Homology") Searching. Curr. Protoc. Bioinform. 2013, 42, 3.1.1-3.1.8. [CrossRef]

45. Gomez, E.; Ferreras, L.; Lovotti, L.; Fernandez, E. Impact of glyphosate application on microbial biomass and metabolic activity in a Vertic Argiudoll from Argentina. Eur. J. Soil Biol. 2009, 45, 163-167. [CrossRef]

46. Ataikiru, T.L.; Okpokwasili, G.S.C.; Okerentugba, P.O. Impact of Pesticides on Microbial Diversity and Enzymes in Soil. South. Asian J. Res. Microbiol. 2019, 4, 1-16. [CrossRef]

47. Swensen, B.; Bakken, L.R. Urease activity and nitrification potential in a mineral subsoil. Soil Biol. Biochem. 1998, 30, 1333-1341. [CrossRef]

48. Baboo, M.; Pasayat, M.; Samal, A.; Kujur, M.; Maharana, J.K.; Patel, A.K. Effect of Four Herbicides on Soil Organic Car-Bon, Microbial Biomass-c, Enzyme Activity and Microbial Populations in Agricultural Soil. IJEST 2013, 3, 100-112. Available online: http:/ / www.urpjournals.com (accessed on 11 January 2021).

49. Richardson, D.M.; Pysek, P.; Rejmanek, M.; Barbour, M.G.; Panetta, F.D.; West, C.J. Naturalization and invasion of alien plants: Concepts and definitions. Divers. Distrib. 2000, 6, 93-107. Available online: http:/ / www.blackwell-science.com/ddi (accessed on 11 January 2021). [CrossRef]

50. Pant, H.K.; Warman, P.R. Enzymatic hydrolysis of soil organic phosphorus by immobilized phosphatases. Biol. Fertil. Soils 2000, 30, 306-311. [CrossRef]

51. Fuentes, B.; Bolan, N.; Naidu, R.; de la Luz-Mora, M. Phosphorus in organic waste-soil systems. J. Soil Sc. Plant. Nutr. 2006, 6, 64-83. [CrossRef]

52. Martiny, J.B.H.; Bohannan, B.J.M.; Brown, J.H.; Colwell, R.K.; Fuhrman, J.A.; Green, J.L.; Horner-Devine, M.C.; Kane, M.; Krumins, J.A.; Kuske, C.R.; et al. Microbial biogeography: Putting microorganisms on the map. Nat. Rev. Genet. 2006, 4, 102-112. [CrossRef] [PubMed]

53. Martinez-Salgado, M.M.; Gutiérrez-Romero, V.; Jannsens, M.; Ortega-Blu, R. Current Research, Technology and Education Topics in Applied Microbiology and Microbial Biotechnology. In Biological Soil Guality Indicators: A Review; Mendez-Vilas, A., Ed.; FORMATEX Microbiology: Badajoz, Spain, 2010; Volume 2, pp. 319-328.

54. Wyszkowska, J. Effect of soil contamination with Treflan 480 EC on biochemical properties of soil. Pol. J. Environ. Stud. 2002, 11, 71-77.

55. Wyszkowska, J.; Kucharski, J. Biochemical and physicochemical properties of soil contaminated with herbicide Triflurotox 250 EC. Pol. J. Environ. Stud. 2004, 13, 223-231.

56. Yao, X.-H.; Min, H.; Lü, Z.-H.; Yuan, H.-P. Influence of acetamiprid on soil enzymatic activities and respiration. Eur. J. Soil Biol. 2006, 42, 120-126. [CrossRef]

57. Baćmaga, M.; Boros, E.; Kucharski, J.; Wyszkowska, J. Enzymatic activity in soil contaminated with the Aurora 40 WG herbi-cide. Environ. Protect. Eng. 2012, 38, 91-102.

58. Dhillon, A.; Sharma, K.; Rajulapati, V.; Goyal, A. Proteolytic Enzymes. Curr. Dev. Biotechnol. Bioeng. 2017, 149-173. [CrossRef]

59. Subrahmany, G.; Archana, G.; Chamyal, L.S. Soil Microbial Activity and its Relation to Soil Indigenous Properties in Semi-arid Alluvial and Estuarine Soils of Mahi River Basin, Western India. Int. J. Soil Sci. 2011, 6, 224-237. [CrossRef] 
60. Kwiatkowski, C.A.; Harasim, E.; Feledyn-Szewczyk, B.; Antonkiewicz, J. Enzymatic Activity of Loess Soil in Organic and Conventional Farming Systems. Agriculture 2020, 10, 135. [CrossRef]

61. Kompała-Baba, A.; Bierza, W.; Sierka, E.; Błońska, A.; Besenyei, L.; Woźniak, G. The role of plants and soil properties in the enzyme activities of substrates on hard coal mine spoil heaps. Sci. Rep. 2021, 11, 5155. [CrossRef] [PubMed] 